perience and success as a state corporation advising the government in the interest of South African industry, can influence government to adjust politics to economic dictates, rather than the opposite?

\section{Managers as pioneers of social innovation in South Africa}

\section{John Simpson}

Director, Graduate School of Business, University of Cape Town, Cape Town 8000, Republic of South Africa

Paper delivered by Prof. John Simpson at Le Groupe de Talloires 1981 International Colloquium of Business leaders and academics, Talloires, France on October 2, 1981

The theme of this colloquium - Management's role as pioneers of social innovation - is entirely appropriate for my country and it has been the subject of discussion and soul searching by many of our executives, politicians and academics. I would like to report to you what progress has been achieved in this regard in South Africa, and what we can expect in the future, and shall start by attempting to summarize for you some of the social, political and economic parameters which are relevant to my talk.

South Africa is a relatively small country in economic terms. In 1980 it had a Gross National Product of $\$ 68000$ million. It attracts a disproportionate amount of attention in the international communications sphere, if only because of its uniqueness in many respects. For example, it is the sole supplier - or near sole supplier - of certain minerals upon which many international industries are dependent. It boasts a well-known heart surgeon, but probably, the major reason for this focus of attention on South Africa is its government's politics. It is, as far as I am aware, the only country in the world where racial differences are maintained by legal entrenchment, although I have no doubt that racial discrimination is practised in many other countries. World attention and indeed antagonism - took a quantum step forward in the 1960s and again in the latter half of the 1970s when racial violence occurred in the country. Whether by accident or design - probably both - it is a highly heterogeneous society. What I think is of paramount importance is the fact that so much that has taken place in South Africa since World War II at least, whether it be in the political, the social or the economic spheres, has been overlaid with concerns about race.

\section{Many paradoxes}

South Africa is a country of remarkable paradoxes though. The economy has been characterized by relative ly high growth in the last 12 years but also by high unemployment. Interestingly, in this regard, we note a tremendous shortage of management and skilled labour on the one hand, and massive unemployment among unskill- ed members of our society on the other. Here too, the dividing lines are to some extent characterized by race. We note that to some degree, the buoyancy of the economy is the result of a group of independent thinking, successful entrepreneurs, capitalizing on the world's propensity to buy gold and other minerals on the one hand, but, on the other, also of government involvement in a host of state and semi-state bodies assuming a pivotal and monopolistic role in the economy. On top of that, despite government's apparent commitment to a free enterprise system, the economy is in fact highly regulated, as is reflected by imposed price, foreign exchange and import controls, and restrictions on black labour movement, to name a few.

The shape of the economy is also riddled with paradoxes. Having massive resources of a number of essential commodities, South Africa is in many ways self-sufficient; but owing to its lack of petroleum resources, it is dependent on many of its major critics for these crucial products. Yet, owing to its large deposits of coal and uranium, it will be a net exporter of energy by 1983.

Historical, political, legal and cultural factors have resulted in yet another paradox in the sharing of the spoils of the buoyant economy. On the one hand, we see a small group of highly affluent people whose manifestations of wealth rival even the population of Southern California! On the other hand, the majority of the population have incomes which are only somewhat higher than those of their third world compatriots. Again, the lines which distinguish the 'haves' from the 'have-nots', have until recently been largely determined by race, with the whites making up less than $20 \%$ of the population. In 1980 , average annual earnings per white wage/salary earner were estimated to be slightly more than $\$ 8700$. Urban black wage and salary earners averaged about $\$ 2200$ in the same period.

Massive economic growth in recent times has stretched South Africa's skilled manpower resources to the limit and the obvious future potential will only be achieved if more and better skilled, willing personnel can be acquired; but past political policies and continued intransigence in some government quarters have restricted optimal utilization of South Africa's manpower. Fundamentally, it is these two factors - the need for skilled staff and government's apparent failure to adequately ensure such human development in the past - which have motivated management to look to taking on the role of being pioneers of social change. As a business academic I find this point to be of particular interest. In my view, managers are generally a particularly conservative group, especially when profits are high - which they are in South Africa. And yet, it is my contention that they have been remarkably innovative in South Africa, probably because of government's apparent abdication of its role in this regard. Perhaps we should try to identify the reasons for this remarkable situation.

\section{Political history}

Historically, in the early days, South Africa was settled by groups of European political dissidents and administrative representatives of certain colonial powers. Before long they met up with migrating tribal blacks and very soon, owing to superior education and experience on the 
side of the white settlers, a master/servant relationship developed. This has been in evidence to some degree ever since. After World War II, when the present Nationalist Government came into power, its major concern - indeed its successful political platform - was to ensure the master's position of the whites - particularly the Afrikaans-speaking element of our country. This group had in the past felt considerably threatened by the white English-speaking community who dominated business, and by blacks who were able and willing to offer their services in the job market at markedly lower rates than those asked by the so-called 'poor whites' who were primarily Afrikaners. It is interesting to note that even as late as 1962, the focus of government attention remained on politics, rather than on economics. The then Prime Minister, Dr Verwoerd, said in Parliament: 'Fundamentally, South Africa's problem is not one which has to do with its economy. Basically, her problems lie in the political sphere'. Quite clearly, he believed that economic factors were an adjunct to his political views. They had a viability of their own, but were by-products of a central, all-embracing philosophy. He and his ruling party stood for out and out segregation in government, in the economy and also in society. The fundamentality of the approach - which still persists in some government thinking - has resulted in a complexity of economic and social, and recently political, problems which have had a marked impact on the business community in their strivings to capitalize on the opportunities potentially available.

As far as blacks were concerned, they saw themselves as being, at best, temporary sojourners in urban white South Africa, providing their services when called upon, but basically in terms of the philosophy of apartheid. Indeed, in many ways the Verwoerd thinking did not so much excise blacks from the economy - a far too drastic step even if that was his ultimate intention. It did, however, prevent blacks from making the headway that they would have made, had they been given the opportunities, the means and the encouragement. Perhaps the most significant outcome of Dr Verwoerd's philosophy was that it made the blacks feel servile to the system, and yet believe that they were not fully part of it.

The other critical step undertaken by the Nationalist Government was to ensure that economic power did not remain exclusively in the hands of the English-speaking South Africans. To achieve this, they set up a number of state-owned or semi-state-owned industries, such as the South African Coal, Oil and Gas Corporation, marketing control boards for various agricultural products, etc. They vested further control in the infrastructure by way of limiting competition from the private sector with transport agencies, electricity supply, and such services. In most cases, they actively attracted Afrikaans-speaking South Africans to control these economically critical government and quasi-government organizations. One must admit, however, that these corporations were set up by the government to provide products and services that were essential to the country's economic development, and that most of these projects were of such a size that the private sector could not, or would not, undertake these ventures. Also, in the late 1940 s and 1950s, many young Afrikaans-speaking economists, engineers and other professionals were available to staff the large corporations because of the high value that most Afrikaners placed in university education; with many of them having proceeded to master's and doctor's degrees while their English-speaking peers started out early in their business careers.

Turning to the present, the reactions of many South Africans to the government policies are perhaps not entirely surprising. Among many of the whites - particularly blue collar workers and state employees who make up about $40 \%$ of the white work force - we note a resistance to change, a desire to maintain their status quo simply because this prevents any threat to their position in society. One of the trends in the white electorate is a measurable swing towards the right. This is significant in the sense that the present Prime Minister sees a threat both from without his party (HNP) and from within, and this movement has certainly gone a long way to restrain him in terms of any liberalization in policy. However, among white entrepreneurs, there is growing realization that better utilization of all members of the population in the work-place is imperative for economic, political and social reasons; hence, there is some pressure on government to introduce appropriate change.

\section{Some black views}

Research undertaken among blacks by the Graduate School of Business of the University of Cape Town suggests, not surprisingly, that the restraints that have been placed upon them in terms of employment, plus the overt manifestations of wealth which are primarily in the hands of the whites, have caused this group to look upon the free enterprise ethic with cynicism, distrust, suspicion and in many cases, outright rejection. We limited our research to literate urbanized blacks, feeling that this group could to a large degree be regarded as opinion leaders. Indeed, history shows quite conclusively that most major social disruptions and revolutions have their origins in the middle classes, among educated people, and while it is not suggested that this 'elite group' necessarily reflects the opinions of all of black society, we do believe that it could give some indication of future attitudes and views of the vast majority of urbanized blacks.

Our research, jointly undertaken with BP Southern Africa, has revealed a number of disturbing trends.

Essentially, the expectations of this 'above-average' group have not been met socially, politically or economically. They hear politicians promising them a greater say in the determination of their political destiny, but they do not see any evidence of this occurring. Indeed, there is evidence of a track record of considerable intransigence in this regard. They also see companies aligning themselves with the equal opportunity ethic; yet they can identify very few blacks in any positions of seniority. In the meantime too, they who value education, are aware of the fact that educational opportunities are improving all the time, but do not perceive appropriate job opportunities becoming available to blacks. Note that in 1981, more than 300000 blacks will leave school and enter the job market. Blacks are also told that the basic living conditions to which they are subjected will change; but they continue for the most part, to live in the same dull, unattractive, undifferentiated, inadequate 'look alike' homes, 
in locations exclusively reserved for blacks in terms of an act of Parliament called the Group Areas Act which determines where each race group may live. They associate these inequities with the free enterprise system, since they see it linked inexorably with the political system of apartheid.

Clearly then, the free enterprise system (as practised in South Africa) is of little immediate benefit to the vast majority of blacks; they do not participate in it; they don't advance within its framework either in society or in terms of job advancement, and the frustrations that result inevitably turn them to look to some other system which they feel may better accommodate their needs. And those systems with simplistic slogans which appear to sympathetically address the issues which concerns them are those which are currently attractive. From the businessman's point of view, you will appreciate therefore, that these trends are extremely disturbing.

\section{Business and black advancement}

Many of the more progressive members of the business community see the necessity to involve themselves heavily in black advancement for economic, political, moral and social reasons. This seminar has, over the past few days, addressed the question of 'why' with regard to the need for social innovation. We contended that where there was perceived inequality, injustice or where the quality of life was relatively inferior, then there is a need for social innovation. I would suggest that these South African businessmen think the same way.

However, from the foregoing it must be apparent that there are a number of institutional constraints which may severely hinder these pioneers in achieving their goals which in many instances are not too clearly identified anyway. These constraints are listed below:

Political. Despite political statements to the effect that massive social change can be expected, there is only limited evidence at this stage to support this.

White intransigence. Rejection by right-wing white workers through their organized labour unions which have indirect but considerable influence on government policies.

Education. Education is separate, often sub-standard, and not always appropriate for black advancement in the workplace. Indeed, during our research to which I referred earlier, one of our respondents summed this up very succinctly. He said: 'While scientists are sending men to the moon, we are taught in school how to make brooms from grass'.

Management stereotyping. Many members of management still hold stereotypes - one may even classify it as rank prejudice - about black people's innate abilities which certainly inhibit black advancement.

Black culture. Cultural and attitudinal factors also prevail to the disadvantage of black advancement. Many blacks - as we have seen - have decidedly negative views of the free enterprise system, but what is perhaps equally problematical, is the fact that the culture from which many emanate has value systems not necessarily akin to the protestant ethic which is crucial to the success of the free enterprise system. Communalism, which is typical of many black societies, emphasizes group consensus and group sharing rather than individual performance resulting in personal achievement, recognition and promotion. Clearly, any attempt to introduce blacks to the free enterprise value system and to integrate them into it, is both complex for management and sometimes traumatic for some of the participants.

Social mobility. Restraints on the development of a normal class structure by limiting home ownership and physical mobility has had major implications for businessmen wishing to advance blacks within their organizations, simply because job mobility cannot be matched with social mobility beyond the workplace.

Migrant labour. The policy of migrant labour, which is sex, age and education selective, is a dislocating one. Migrant labourers who tend to be males, younger and of lower education, make up more than $40 \%$ of the urban black work-force. They are traditionally a part of the labour force and it is unlikely that the system will be phased out in the near future. They are, of course, 'temporary' in almost every sense.

In order to tackle these issues, thinking management has come to realize that any changes in the work-place and beyond will have considerable social impact as well. Indeed, the two go hand in hand, and social change which can be expected will occur among blacks as well as whites. Management certainly does not underestimate the enormity of their task, nor the importance of $i t$, as is evidenced by their personal involvement in it. For example, the executive chairman of Gold Fields of SA, Mr Robin Plumbridge, has personally taken on the Manpower portfolio; the chief executive of Volkswagen SA, Mr Peter Searle, estimates that in excess of $60 \%$ of his time is spent on these issues. We are conscious too of the major efforts put into these issues at corporate and national level by such business leaders as Mr Mike Rosholt of Barlow Rand, Mr Harry Oppenheimer of Anglo American, Dr Willem de Villiers of General Mining, Mr Kerneels Human of Federale Volksbeleggings and Dr Anton Rupert of Rembrandt. As I hope to show, these men are really leaders in the broadest and truest sense of the word.

\section{What has management achieved?}

In the political sphere, management, together with the Wiehahn Commission and the innovative Minister of Manpower, Mr S.P. Botha, have had some success in persuading government to introduce changes in labour legislation which are already having profound effects. Firstly, government has entirely repealed the job reservation act - a piece of legislation which precluded blacks from taking up certain types of occupation, designed initially to safeguard the 'poor whites'. Although job reservation affected only $2 \%$ of all jobs in South Africa, it created a negative climate with regard to black advancement, and a ready excuse for employers to keep blacks in lowly positions in the past. The recent changes in the labour field, however, now allow, and in fact encourage management to legally indulge in selecting blacks for training for advancement purposes in a number of areas hitherto the exclusive domain of white workers. But what 
is perhaps even more significant is the fact that in many instances, this change in legislation has affected white management's attitudes with regard to black advancement in the broadest sense.

Secondly, blacks may now join trade unions which are legally recognized by both management and government; this makes their position so much stronger in negotiating with management. This has given black workers an awareness of power, and could also be the pre-cursor of a new socio-political system within black society, simply because the development of such systems has been limited in the past. We already see such unions being used by political leaders as a vehicle to promote their own acceptability among their people. In the past, black leaders who negotiated with the authorities in any way were immediately regarded with suspicion by followers. A powerful, militant union which overtly confronts the system, clearly is an ideal vehicle for leadership recognition and acceptability. Many large corporations acknowledge that these moves may not be advantageous for the free enterprise system and that their role is to assist unions to become effective representatives of workers striving for recognition and achievement in the workplace, but within the economic system. Some have gone on record that not only should management receive training in industrial relations, but so too should members of the workforce indeed union members - so that these fledgling, dynamic organizations can participate in the whole negotiating process in an orderly and more successful fashion, in the interests of all concerned.

You may be interested to know that at Cape Town University's Graduate School of Business, we now run a course in business methods specifically for trade union representatives so that when they negotiate with management, discussions will be along common and understood lines, and trade unionists will be able to talk from strength, instead of weakness. This can help to avoid dysfunctional confrontation.

But perhaps it could be said that management's major contribution has been its active participation in the development of the National Manpower Commission which advises government with regard to future manpower policies. This forum, which includes trade unionists, academics, businessmen and government officials, has created the opportunity for business to air many of their concerns, and present them to government through this body. It may well be that many of the policy changes which have taken place in the labour area, were the subject of debate - indeed in some case were initiated - by this group.

A further development which management can claim, is in the area of codes of employment and conduct. Many companies now publish these, which reflect the philosophy of equal opportunity - indeed advancement - irrespective of race, sex or any other factors. Some companies have gone so far as to lay down time scales specifying points at which certain achievements in black advancement should be expected. The ramifications of these policies not only on these companies' staff but on black society in general. could be profound.

\section{Some obstacles to be overcome}

However, publication of such codes, and management's conversion to an equal opportunity and black advancement philosophy are in themselves admirable, but not enough to ensure success. There are a number of restraints which need to be tackled.

Firstly, within the company itself. Here we encounter resistance from right wing white staff - particularly at artisan level. Such intransigents may have to be coerced into accepting black workers in equal - if not senior positions. Success in this quarter will go a long way to achieving harmonious relations and racial tolerance - if not integration - in society as a whole. Many members of middle and senior management presently hold stereotypes on black peoples' innate abilities - or inabilities to advance. Clearly, a dispelling of such stereotypes is critical for the success of any black advancement programme.

The inevitable narrowing of the wage gap will also have societal implications as blacks have more discretionary spending and start to buy luxury goods, hitherto never even considered and generally purchased only by the more affluent white members of the community.

Secondly, beyond the workplace, management will have to contribute by word and deed to ensure a restructuring of society into more naturally evolving social classes. This can and is being done to some degree by contributing to housing schemes in black townships which would allow black employees to 'trade up' socially into dwellings more reflective of their position. Volkswagen, for instance, is doing this directly; other companies channel their funds through such institutions as the Urban Foundation, which then implement such social policies not only for the sponsoring companies, but for the good of society in general. One measure of management's committment to change is their contribution to this body which came into being shortly after the 1976 unrest, when a group of senior business leaders came together to decide how they effectively could contribute towards the amelioration of the reasons for the social unrest. One of the conclusions was that an independent body such as the Urban Foundation sponsored by the business community, could carry out social research, and develop projects to advance black communities in a number of ways; indeed, could act as a catalyst for change. Probably, their major thrust has been in the area of home ownership and home improvement. To date, more than $\$ 45$ million has been donated by over 300 South African companies to the Urban Foundation.

There are certain constraints associated with the concept of improving the life style of blacks. Firstly, central government still precludes blacks from owning land, although they do allow a 99 year leasehold scheme in certain cities, but this has not been particularly effective. Secondly, there is considerable debate about whether or not money should be channelled into sub-economic mass housing instead, to satisfy the burgeoning demand at the bottom end of the scale. The black birth rate remains very high - about twice that of the whites - and at present, with only $34 \%$ of blacks being urbanized, there is growing pressure from many of the balance of the black population to re-locate; the housing implications are therefore tremendous. Some estimates put the backlog 
for housing at nearly 500000 units today; by the year 2000 , the need will have increased to over three million units, unless an effective housing programme is initiated soon.

The social implications of differentiated, personallyowned housing are significant. It results in the formation of a social class structure; it encourages people to seek personal promotion in the workplace; it changes peoples' attitudes towards private property and also, it inculcates a feeling of social permanence.

\section{Promoting entrepreneurship, education and train. ing}

Largely at the instigation of members of the business community - Dr Anton Rupert's name is often most prominent - we have seen a well-financed Small Business Development Corporation being set up. This body, which is funded by a wide range of representatives of the private sector, aims to complement the government's efforts in this area, to assist small businesses to prosper, by way of financing them, by offering them advice and training.

Clearly, the thinking behind such a move is that the encouragement of small businessmen, especially among the black community, will assist in creating a more effective and substantial entrepreneurial middle class, a safeguard for the free enterprise system. It will also help create more jobs, experience elsewhere showing most conclusively that smaller, developing companies employ relatively more people than larger established organizations.

A number of business leaders do articulate conceptual concerns about the likelihood of success of the SBDC in general, and question how many small fledgling businesses will be able to compete against the established, more efficient concerns, particularly in the retail and engineering areas. Others question whether the cost will be justified. Whatever views are held, the fact of the matter is that in South Africa, private enterprise has seen reason to contribute substantially towards the growth of a middle class, particularly among blacks, in the belief that such a move will, in the long term, assist in the overall improvement of the general position of the black community. It is also quite possible that this body can bring pressure to bear on government to relax many of the existing regulations which make business operations difficult for black businessmen.

The business community is also looking to education as a means of change, although there is some evidence to suggest that in the short term at least, education in isolation has a limited effect on cultural value change. However, it is a start, particularly if management is prepared to involve itself in 'grass roots' education expansion and improvement, even if the pay-off to society is somewhat long-term. Companies are also striving to broaden the scope of secondary education, to make it more appropriate to the needs of the business community and hence to ensure employment opportunities for graduates. However, there is a limit to what can be done, because the actual syllabus design is under the control of a government department; but more important, there is at this stage some evidence of a stigma associated with technical training, with many young blacks opting for education which will lead to a profession or to white col- lar employment, while the economy's major needs are in a technical area.

In-company training as a means of upgrading present employees is also being undertaken on a limited scale. However, the greatest need is seen by some in the area of developing 'the right attitude' in potential black middle and upper management, that is a higher level of achievement orientation, individuality and career commitment. These companies see a need to integrate blacks, who have reasonably high academic capabilities, into a white community at either high school or university level. Such programmes are, of course, fraught with danger, many blacks seeing them as an imposition as management tries to force them into accepting a system which is apparently rejected by a large proportion of blacks.

I would like to pause here for a moment. It is evident that management has decided upon a course of action which to a large extent has as its basis, the free enterprise system or a variation of it, with its concomitant value systems. It may be said that this is an imposition. But either out of conviction or from research, management by and large has made its decision. Incidentally, as part of the GSB research among blacks, we asked our respondents to rank areas of change which they would like to see taking place. Two years ago, the order was: education - leading to better acceptability and political say - $\quad$ in determining their own destiny removal of - such as limitations on movement, restrictions where to live, etc.

economy - greater involvement/share in the economy

I am, of course, very aware of the limitations of attitudinal research. There is considerable evidence that articulated attitudes do not necessarily predict consequent behaviour. But still, it does give us something to work on, and the research does indicate some support for management's actions with regard to social innovation.

\section{Managers as agents of change}

Roger Talpaert, in his fascinating and thought-provoking paper read at the start of this colloquium, said (with regard to management's role in social innovation):

Management must first have a sense of purpose some sort of consensus - about where they want to go. Then they have to develop a sufficientlyeffective mechanism for social application to implement it.

It seems that South African management has to some degree been striving to fulfil these requirements.

Mining contributes about $20 \%$ towards the country's Gross National Product. For economic, social and political reasons, it can be regarded as a barometer of change in South Africa. The mining industry has long been dependent upon migrant labour. Mining organizations have for years recruited healthy, often uneducated black males from rural areas to contract them to work for one year at a time. At the end of the year, these labourers return to their homes and are given the opportunity to offer themselves for contract for yet another year's employment. The rate of re-registration has generally been very high, reflecting the unemployment in the rural areas from which they came. 
In many ways, this approach to employment reinforced the essentially tribal nature of the participants, since the young men lived in dormitories and hostels, segregated by their tribe of origin; and inter-tribal disagreements were not unusual.

Recently, the mines have attempted to stabilize the work-force by encouraging permanent employment and by developing facilities so that families can live together on the mines. Beyond that, they have involved themselves in educational upgrading schemes for staff and their families and they have also made attempts at integrating the work-force, irrespective of tribal affiliations. It is a slow, expensive process but in the long term it is seen by many executives as making economic and social sense. Opportunities for advancement are being developed, but strong resistance is frequently presented by the white unions which in this industry are particularly recalcitrant to social change. When one considers that in 1980 over 700000 people were employed in mining, of whom $90 \%$ were black, it will be seen that this industry faces an enormous task, irrespective of the degree of sympathy held by management for the concept of social and economic change amongst its workforce. Success in this area of South Africa's economy certainly bodes well for the country at large; failure could point to problems of cataclysmic proportions.

I have tried to summarize for you the challenges which face management in South Africa as pioneers of social innovation. It is evident from my talk that my thesis is that the type of society which businessmen and business academics in South Africa want, is one which is at least similar to a capitalist society with its concomitant free enterprise ethic. So management is bound to steer change in the direction of free enterprise.

Given the prevailing circumstances, particularly black attitudes and government involvement in the economy, it is questionable whether free enterprise is a marketable commodity to the majority of the country's inhabitants. In order to ensure that the system can offer benefits to the participants, it must be just, fair, colour blind and provide scope for equal opportunities.

Management's major task then is to ensure change in the constraints that exist at present - at both a macro level, and a micro level. It is evident that government indeed most whites for that matter - resist the change which is so necessary, and management's task is therefore both vast and complex. It has been said that business alone cannot make a society flourish; I believe though, that in South Africa, without business's involvement in society in the broadest sense, it will progress very little. That management has a role to play in this regard must be unquestioned, and I do believe that management has already identified and tackled some of the areas where social and economic change is so necessary. But for the good of South African society, there is still so much to be done. It is at once a bewildering, complex and timeconsuming task, and a critical challenge. I would like to close by quoting a prayer which Martin Luther King was wont to use. I believe that it is rather apt.

'Lord, we ain't what we ought to be,

we ain't what we'd like to be,

we ain't what we gonna be,

but thank God we ain't what we was.'

\section{Israel and the problem of infla-} tion

\section{Yair Aharoni}

Professor, Leon Recanati Graduate School of Business Administration, Tel-Aviv University, Ramat-Aviv, Tel-Aviv 69978, Israel

Talk delivered to staff and students, Graduate School of Business Administration, University of the Witwatersrand, Johannesburg, September 3 , 1981

Israel, although a small country, has big problems of which, aside from security problems, inflation is one of the most pungent. Before telling you something about how the business community in Israel lives with the problem of inflation - a few background details on trends in three major areas: defence expenditure, the expansion of social services and economic growth.

Defence expenditure has been growing exponentially since 1973 after a short remission in the early years of the seventies. The Peace Treaty with Egypt has brought no relief; in fact expenditure has increased to accommodate the deployment of the army and airport bases to new sites outside the Sinai.

Thirty-two years ago, when the State of Israel was established, the amount of money spent on social services was low. Since then it has been increasing in line with world trends. Also, the efflux of time coupled with good health services has changed the small proportion of population at the upper peak of the age pyramid into a sizeable and increasing segment of our society. Israelis, like their counterparts anywhere else in the world, make frequent calls on the national health service, which is rapidly growing more sophisticated, more equipmentoriented and therefore more costly. These trends are there to stay.

The high growth rate of $10 \%-12 \%$ during the sixties made possible the high level of defence and social service expenditure. The war cost Israel the equivalent of the Gross National Product for one year, - plus an amount which still has to be paid. At the same time, the economic conditions were drastically affected by rising oil prices. These prices can be compared to a foreign tax on the economy, and like taxes, cannot be avoided.

By the end of the seventies, Israel had changed from a 'welfare' to an 'insurance' state: everybody became insured against every calamity - loss of job, loss of profit, movement to new jobs in new areas - everything. The state had taken onto its own shoulders the task of protecting the whole population against the effects of change. As a result, Israel is now left with very little room for manoeuvre. Everybody agrees that the government should cut expenditure, but it is impossible to name any specific cut without an outcry from somebody. Democratic societies breed a sense of entitlement: the 'why-should-I-lose-out' syndrome. Defence costs at $40 \%$ of the total budget are high but nobody believes they can be reduced; to effect even small cuts in the social programme demands a change in the law; and the social cost of large-scale unemployment is considered to be too high a price to pay for reducing inflation. The result is that the 